症例

下行結腸脂肪腫による腸重積に $\mathrm{S}$ 状結腸癌を合併した 1 例

\begin{tabular}{llllllllllll}
\multicolumn{10}{c}{ 大田原赤十字病院外科 } \\
田 & 村 & 明 & 彦 & 赤 & 松 & 秀 & 敏 & 半 & 田 & & 寛 \\
伊 & 澤 & 祥 & 光 & 松 & 田 & 純 & 一 & 松 & 井 & 淳 & 一
\end{tabular}

症例は55歳の女性て 1 週間前よりの腹痛, 便秘を主訴に当院受診, 腹部単純X線にて 大腸閉塞の疑いで入院となった。内視鏡にて S 状結腸に内腔を占拠する可動性のある腫 瘤を 2 個認めた. CT では脂肪腫による腸重積が疑われ, 手術となった. 開腹すると下行 結腸から S 状結腸が重積しており一塊として切除, 覀性疾患も考虑してリンパ節郭清(D

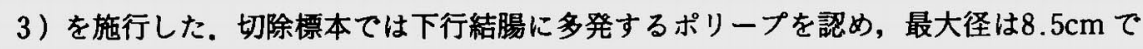
あった. ポリープによる重積の先進部と思われる $\mathrm{S}$ 状結腸に径 $2 \mathrm{~cm}$ の 2 型の癌を認め た. 病理学的には墏膜下組織由来の良性の脂肪腫と, 筋層に浸潤する中分化腺癌の診断 であった. 大腸脂肪腫は癌を合併しやすいとされ, 本邦報告例 36 例中, 本症例のように 両者が近接していたのは11例で,うち 9 例は脂肪腫が癌の口側または同じ部位に存在し, 慢性的な接触があったと思われ発癌に関与していた可能性が考えられた。

索引用語：大晹脂肪腫, 大腸癌, 腸重積

\section{緒 言}

大晹脂肪腫は稀な疾患であり，悪性腫場を合併する 㹕度が高いとされている．最近われわれは，下行結腸 の多発性の脂肪腫による腸重積の先進部に大腸癌を合 併した症例を経験した，極めて稀と考えられるため， 文献的考察を加えて報告する.

症例

患者：55歳，女性.

主訴：腹痛, 便秘.

家族歴・既往歴：特記すべきことなし。

現病鳫：2000年 8 月 4 日よりの周期的な左下腹部 痛，8日よりの便柱狭小化，11日よりの少至の鮮血便 にて14日当院受診となった。

入院時現症：体温 $36.3^{\circ} \mathrm{C}$, 血圧 $120 / 70$, 脈拍 84 . 貣 血・黄㾝所見なし，左下腹部に压痛を認めたが腫痼は 触知せず，腹膜刺激症状もみられなかった，直腸診に て少量の新鮮血の付着を認めた。

入院時検査所見：WBC $11,600 / \mathrm{mm}^{3}$, CRP $8.0 \mathrm{mg} /$ dl と上昇を認めた。他は特に異常值はなく，腫場マー

2002年12月16日受付 2003 年 1 月17日採用

〈所属施設住所〉

于324-8686 大田原市住吉町 $2-7-3$
カーも正常範囲であった.

腹部単純 $\mathbf{X}$ 線写真：ガスにて㹡張した大腸を認め,

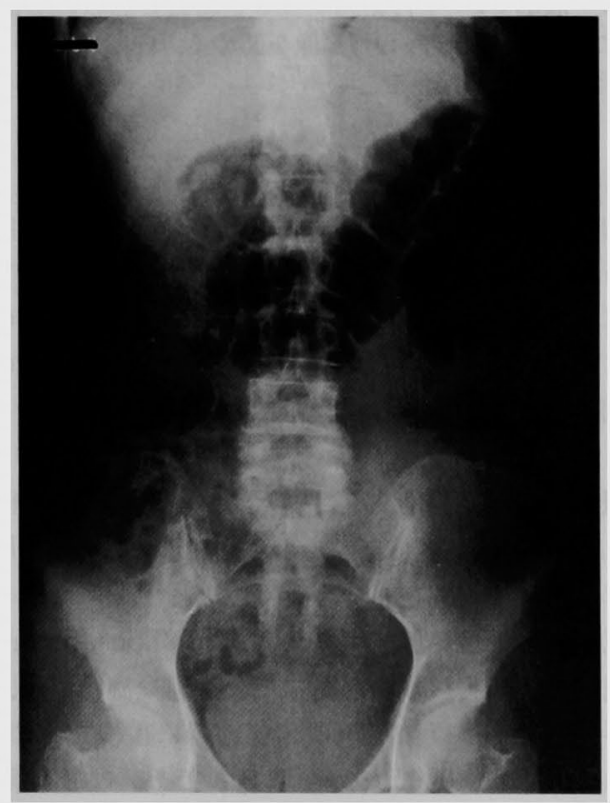

図 1 腹部単純 X 線写真 : 大腸ガス像は下行結 腸にて途絶している. 


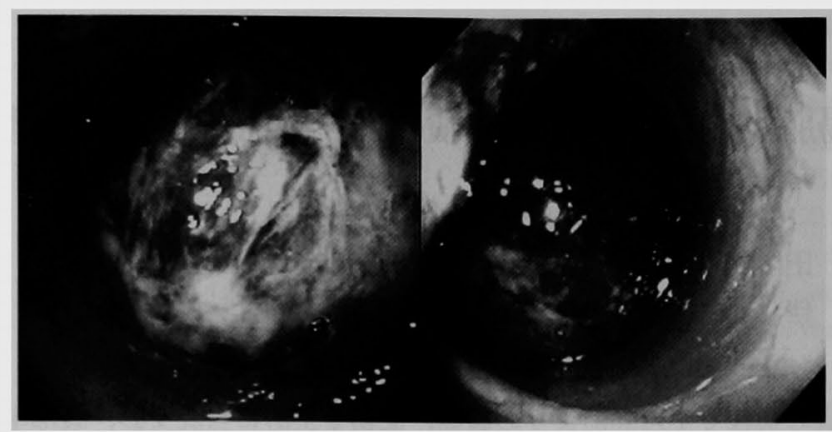

a

b

图 2 大腸内視鏡所見：ほほ内腔を占拠する球形の腫㨨（a）をこす と, 表面粘膜に滾死をともなうもう一つの腫㨨を認めた（b).

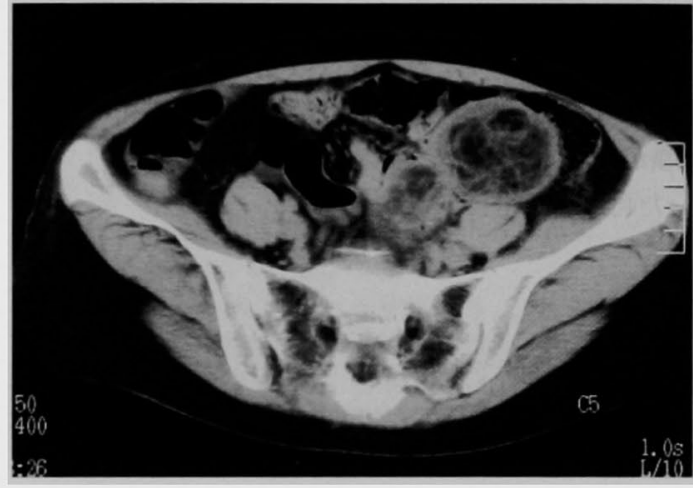

图 3 腹部 CT：下行結腸から S 状結腸と思われる部分 に径 $4 \mathrm{~cm}$ と $3 \mathrm{~cm}$ の腫墇像を認める。内部は不均一で 脂肪レペルの部分を含む。

ガス像は下行結腸にて途絶していた（図 1 ).

内視鏡所見：肛門より $30 \mathrm{~cm} の \mathrm{~S}$ 状結腸にほほ内腔 を占拠する可動性のある腫㾇を 2 つ認めた。球形で表 面にびらん，発赤，壤死をともなっていた，腫寉の口 側に内視鏡を挿入するのは不可能であった。腫瘤の肛 門側にはほかに明らかな異常は認められなかった（図 2 ).

腹部 CT 検查所見：下行結腸から S 状結腸に径 4 $\mathrm{cm}$ と $3 \mathrm{~cm}$ の腫篦を二つ認めた。 内部は不均一て脂肪 レヘルの部分が混在していた（図 3 ).

以上から下行結腸の lipoma または liposarcoma を 先進部とする腸重積の診断にて，手術を施行した。

手術所見：下行結腸から S 状結腸に重積を認めた. 解除は困難であったため一塊としてそのまま切除し た. 術前診断では悪性が疑われたためりンパ節郭清(D 3 )を施行した。腸管内の污染は軽度であり一期的に

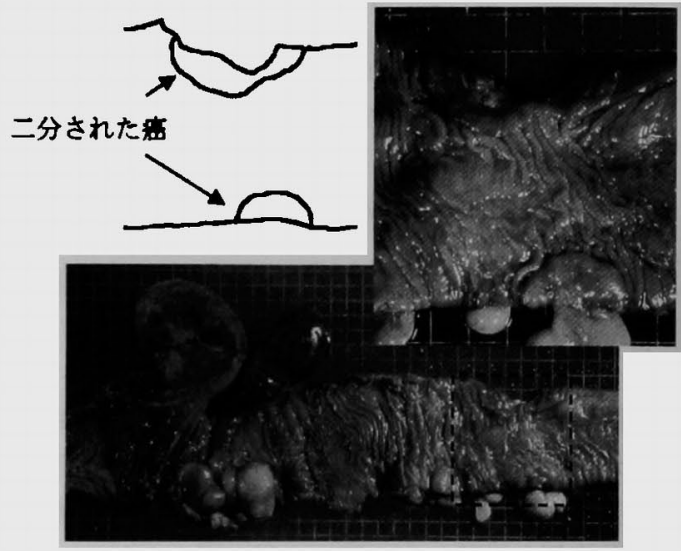

図 4 切除標本：多発するポリープを認め, 最大径は 8.5 $\mathrm{cm}$ であった（下）．肛門側（破線枠内）に周囲とわずか に色調の異なる径 $2 \mathrm{~cm}$ の 2 型の癌を認めた（上右近接 像)。㾑は腸管切開に際し二分されていた（上左シェー マ).

吻合した。

経過は良好にて術後20日目に退院となった。

摘出標本所見：切除標本については重積を解除でき なかったため,腸管を切開して解除，伸展した．口側

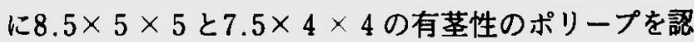
め, 周囲に多発するポリープを認めた。ささらに，ポリ ープの先進部付近の $\mathrm{S}$ 状結腸に径 $2 \mathrm{~cm}$ の 2 型の癌を 認めた。癌は腸管の切開に際して離断されていた（困 4 ).

病理組織学的所見：ポリープ部分はいずれも異型性 のない成熟脂肪細胞よりなり,脂肪腫の診断であった. 表面の粘膜には悪性所見を認めなかった．脂肪組織は 禁膜から筋層を貫通して内腔へと増殖しており，瑟膜 


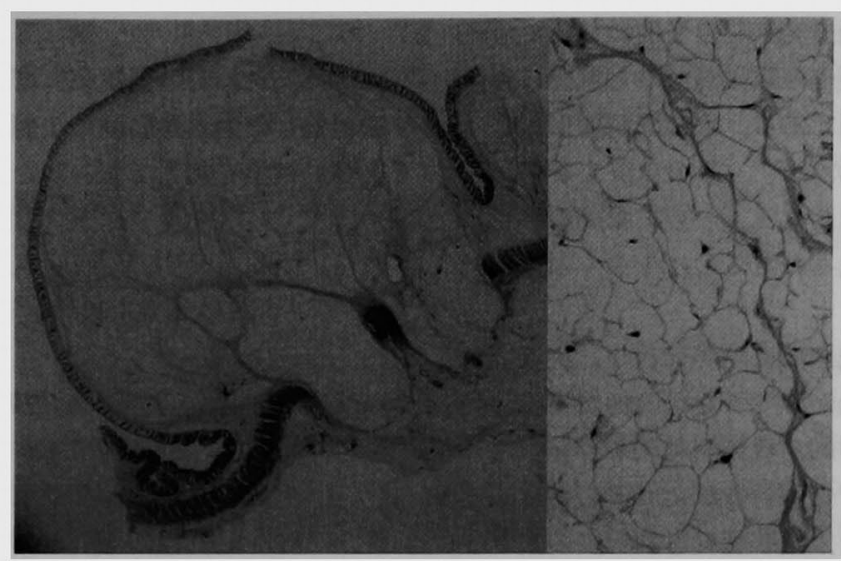

a

b

図 5 脂肪腫の病理組織所見 (HE 染色. a : ルーペ像, b : $\times 100) ：$ ポリープは成熟脂肪細胞よりなる脂肪腫て，策膜下より筋層を貫通 して内㓐へ成長していた，表面の粘膜には悪性所見を認めなかっ た.

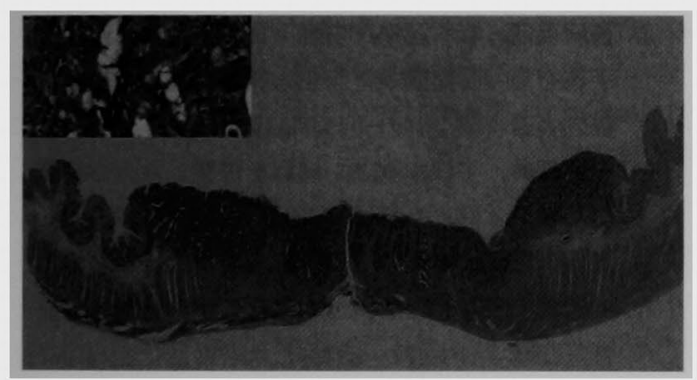

图 6 盤の病理組織所見(HE 染色. ルーへ像, 左上: $\times$ 200)：渒は固有䇨層に漫洞する中分化腺癌であった (mp, INF $\beta$, ly $2, \mathrm{v} 1, \mathrm{n} 0)$.

下由来と考えられた(図 5 )。盘の部分は固有筋首に浸 潤する中分化腺總であった $(\mathrm{mp}, \mathrm{INF} \beta, \mathrm{y} 2, \mathrm{v} 1$ ， n 0 )（图6).

\section{考察}

大腸脂肪腫は比較的稀な疾患であり, Hancock ら" の報告では剖検例において0.3〜 4.4\%とされている. 近年大晹内視鏡の普及にともない報告数が增加してお り，本邦では，野村ら²が1995年に206例について報告 し，最近になって山際ら れらによれば(1) 3), 女性にやや多く, 50〜60歳台に好発 し，右側の大腸が倀位で，ほとんどが粘膜下に発生し， 多発するものは少ない (1.3〜 7.1\%)，2 cm をこえる と腹痛, 便通異常などの症状を認めるようになり ${ }^{3 / 41}$, $4 \mathrm{~cm}$ をこえると重皟の頻度が 31 ～43\%と上昇するも
表 1 最大径 $2 \mathrm{~cm}$ 以上の脂肪便の近傍に大勝瘦を合併 した症例（脂肪腫から癌への距離. 一は癌が口側.）

\begin{tabular}{|c|c|c|c|c|}
\hline & 報告者 年度 症例 & $\begin{array}{l}\text { 脂肪腫と } \\
\text { 最大径 }(\mathrm{cm})\end{array}$ & 瘦 & 距離 $(\mathrm{cm})$, 他 \\
\hline 1 & 石井ら 1949 42F & A, 㑡大 & $\mathrm{A}, \mathrm{m}$ 要？ & 0 , 被㫿粘膜 \\
\hline 2 & 山下ら 1975 83F & $\mathrm{S}, 3$, 有莁 & $\mathrm{Ra} ?, 2$ 型 & ? \\
\hline 3 & 固武ら 1980 63M & I S,2, 有茎 & $\mathrm{R}$ & ? \\
\hline 4 & 石原ら 1980 84F & $\mathrm{S}, 3$, 有壻 & $\mathbf{R}$ & ? \\
\hline 5 & 森ら $198275 \mathrm{M}$ & I C, 棌大 & A.2型 & ?,重㮴 \\
\hline 6 & 森山ら 1985 67F & $A, 4.5$ & A, 0-Isp & -5.5 \\
\hline 7 & 土屋ら 1990 ？ & $\mathrm{A}, 2.8$ & $\mathrm{C}$ & - 数 $\mathrm{cm}$ \\
\hline 8 & 澤井ら $199088 \mathrm{~F}$ & A, 2.6, 有茎 & A,2型 & 重䊧 \\
\hline 9 & 加藤ら 1995 62M & $A, 8.5$ & A, m舟 & 0 , 被蕧粘膜 \\
\hline 10 & 三好ら $199876 \mathrm{~F}$ & $\mathrm{~S}, 2.0$ & $\mathrm{~S}, 2$ 型 & 0 , 対側 \\
\hline 11 & 自匰例 $200055 \mathrm{~F}$ & D, 8.5, 有茎 & $\mathrm{S}, 2$ 型 & 30, 重積 \\
\hline
\end{tabular}

のの 2 , 手術に至った場合の術前診断率は $3 \sim 26 \%$ と 高くはない2)3).

一般的には最大径 $3 \mathrm{~cm}$ を超えるものは腸切除の対 象となり，それ以下では内視鏡的ポリペクトミ一と考 えられるが233)，禁膜下より内腔へと成長するものも報 告されているため注意が必要である5゙.

悪性腫場を合併する率が高く，10～24.5\%に大腸癌 の合併が報告されている3 ${ }^{315)}$. 本邦では1949年に石井 ら ${ }^{6}$ が第 1 例目を報告して以来，1996年までに33例が 報告されている778). それ以後について検索した結果さ らに2 例の報告があり ${ }^{9100}$, 自験例も含めると 36 例と 
なる。また, 山際ら 報告しているが，他の報告と重複があると考えられ， 正確な数については不明である。ほほ同時期に報告さ れた脂肪腫は300例近いため239，癌を合併する率は10 \%を少し上回るものと思われる. 一方大腸癌の手術に ともなって脂肪腫が発見されたものは少なくとも16例 あった。

本症例では脂肪腫の先進部に癌が存在し，大きさと 進行度を考えると癌は後からできた可能性が高く, 長 期にわたり慢性的に化学的, 機械的刺激が存在してい たと思われる.これまでに報告された36例における同 样の症例の検索を行った、脂肪腫にある程度の大きさ がないと相互作用は考えにくいので, 症状が発現した すとされる最大径 $2 \mathrm{~cm}$ 以上のもので, 癌と近接して いたものと，S 状結腸と直腸のように接触する可能性 があったものは11例であった(表 1 ). 被覆粘膜に生じ たものは 2 例, 直接接していたものは重積例も含める と 4 例みられた。 また, 間歇的に重積していた可能性 があるものが 3 例であった。のこりの 2 例は脂肪腫が 癌の肛門側にあり，接触する可能性は低いと考えられ た.

大腸癌の発生部位は時代とともに変化しており ${ }^{11}$, 脂肜腫との位置的な因果関係を解析することは困難で あるが，お互いに接する程度の短い範囲であれば条件 的に同じと仮定し，二項分布，片側検定を行った．脂 肪腫が癌の口側にあるとする仮定は, 統計的には $\mathrm{p}=$ 0.033となり差があるとも考えられる.ただし, 症例数 も少なく, 脂肪腫も癌も成長には長い年月を要するこ とから、どちらが先に発生したかについても議論の余 地があり，因果関係に言及するためにはさらなる症例 の蓄積が必要と思われる。

大腸脂肪腫は, 本症例のように腸重積などで緊急手 街となることも多く，十分な術前検査がなされないこ ともある. 悪性疾㭧を合併する可能性があるため, 術 前に脂肪腫が疑われた場合には癌の合併も念頭におい て手術にのぞむべきであると考えられた。
結 語

今回われわれは腸重積にて㹂急手術となった大腸癌 を合併した大腸脂肪腫の1例を経験したので, 若千の 文献的考察を加えて報告した.

\section{文 献}

1) Hancock BJ, Vajcner A : Lipomas of the colon: a clinicopathologic review. Can J Surg $31: 178$ $-181,1988$

2）野村幸世, 河原正樹, 鹿野信吾他：Bauhin 弁加ら 発生し，腸重積をくりかえした大腸巨大脂肪腫の 1 治験例. 一大腸脂肪腫本邦報告206例の検討一. 日臨外医会誌 $56: 1008-1012 ， 1995$

3）山際裕史, 大西信行, 寺田紀彦他：腸管脂肪腫の 臨床病理学的検討. 消化器科 $35: 462-466,2002$

4) Zeebregts CJAM, Geraedts AAM, Blaauwgeers JLG, et al:Intussusception of the sigmoid colon because of an intramuscular lipoma. Dis Colon Rectum 38:891-892, 1995

5）富岡英則, 青木達哉, 位藤 晋他：腹腔鏡補助下 手術を施行した漿膜下発生大腸脂肪腫の 1 例. 日 踟外会誌 $63: 940-944,2002$

6）石井堯典, 宇根本政之：癌腫を併発した上行結腸 脂肪腫の 1 例. 外科 $11: 247-249,1949$

7）森山茂，松本好市，山本純二他：大腸脂肪腫々 大腸癌の併存した 3 例と本邦報告例の検討. 日臨 外医会誌 $47: 387-392$

8）三好明文, 蜂須賀康己, 福原稔之他: S 状結腸癌に 近接して併存した S 状結腸脂肪弫の 1 例. 日臨外 会誌 $59: 169-173,1998$

9）山下健太郎, 安保智典, 夏井清人他: 大腸脂肪腫 による成人腸重積症の 1 例. 消内視鏡 $11: 629-$ 633,1999

10）山中秀高, 堀 昭彦, 平松聖史他：回盲弁に発生 した脂肪腪を契機に発見された上行結腸癌の 1 例. 日臨外会誌 $62: 983-987,2001$

11) 斉藤 博: 大腸癌の疫学. 安富正幸, 武藤徹一郎, 馬場正三編, 大腸外科, 医学書院, 東京, 1999, p165-169 


\title{
A CASE OF CANCER OF THE SIGMOID COLON WITH INTUSSUSCEPTION CAUSED BY GIANT COLONIC LIPOMAS
}

\author{
Akihiko TAMURA, Hidetoshi AKAMATSU, Kan HANDA, \\ Yoshimitsu IZAWA, Junichi MATSUDA and Junichi MATSUI \\ Department of Surgery, Otawara Red Cross Hospital
}

We report a case of cancer of the sigmoid colon with intussusception caused by giant lipomas of the descending colon. A 55-year-old woman presented with a weeklong periodic left lower abdominal pain and constipation. Colonic obstruction was suspected by a plain abdominal X-ray film. An abdominal CT scan showed obstruction of the sigmoid colon with lipomatous tumors. Colonoscopy found two large round tumors in the sigmoid colon. The tumors were mobile, however, it was impossible to insert a fiberscope beyond the tumors. A sigmoidectomy with lymphadnectomy was performed in an emergency manner. Cancer of the sigmoid colon, $2 \mathrm{~cm}$ in diameter, which might cause intussusception, was found about $30 \mathrm{~cm}$ distal to the lipomatous polyps. Pathological examination showed moderately differentiated adenocarcinoma involving the muscular layer. The polyps with the maximum diameter of $8.5 \mathrm{~cm}$ were benign lipomas originating from the subserosal fat tissue. The cancer was small and hidden under the lipomatous polyps.

We reviewed the Japanese literature for similar cases, and found 11 cases in the recent 52 years in which carcinoma was present adjacent to lipoma. In nine of these 11 cases, lipoma was present just oral to cancer and likely to contact chronically one another. In our case, we consider that these lipomas emerged prior to the cancer may have played a carcinogenic role. 